\title{
INDUCTION OF ACROSOME DEGENERATION OF MOUSE SPERMATOZOA WITH BLOOD SERUM COLLECTED FROM FEMALES IN VARIOUS HORMONAL STATES
}

\author{
R. R. UNNITHAN AND ARAVIND BHATIA \\ Department of Zoology, University of Rajasthan, \\ Jaipur, Rajasthan, India
}

(Received 10th Fune 1974)

\begin{abstract}
Summary. Blood serum collected from female mice treated with oestrogen and progesterone was assayed for its ability to induce acrosome degeneration. The maximum activity was found in serum obtained from females treated with $1.0 \mu \mathrm{g}$ oestrogen/day for 5 days. Lower doses did not produce any significant difference from the control group. Blood serum from pregnant or ovariectomized females treated with progesterone did not significantly depress the incidence of acrosome degeneration. The possibility that removal of the acrosome may not be a morphological concomitant of capacitation in mice has been discussed.
\end{abstract}

Heat-treated blood serum can readily induce capacitation and the acrosome reaction in hamster spermatozoa in vitro (Barros \& Garavagno, 1970; Yanagimachi, 1970). The factors in the serum which induce capacitation are not highly species-specific since heterologous blood sera will also induce similar changes to various degrees. The efficiency of homologous blood serum to induce the acrosome reaction also depends on a variety of factors such as the sex of the animal-female blood serum is more efficient than male blood serum-and the reproductive cycle of the female (Barros, Arrau \& Herrera, 1972). The same authors found that the maximum activity in inducing the acrosome reaction occurred in serum obtained from female hamsters around the time of ovulation and the minimum activity with serum from hamsters on Day 2 of the cycle. Serum from pregnant females and those treated with progesterone significantly depressed the incidence of the acrosome reaction, while treatment with oestrogen significantly increased it.

The present report is the outcome of a study of the ability of blood serum to induce degeneration of the acrosomes of mouse spermatozoa.

Spermatozoa were obtained from the cauda epididymidis of mature randomly bred Swiss albino mice. The caudae from two males were placed in $2 \mathrm{ml}$ Krebs-Ringer bicarbonate solution, with pyruvate and glucose but without bovine serum albumin (Brackett, 1969), under mineral oil and were cut in several places with a pair of scissors, liberating a mass of active spermatozoa 
into the medium. After 10 to $15 \mathrm{~min}$, all pieces of tissue were removed and the suspension was analysed for sperm density and motility.

Blood drawn directly from the heart of animals mildly anaesthetized with ether was transferred to chilled tubes and left to clot at room temperature for $1 \mathrm{hr}$. The clotted blood was centrifuged for $10 \mathrm{~min}$ and the clear serum thus obtained was placed under mineral oil and heated in a water-bath for $1 \mathrm{hr}$ at $56^{\circ} \mathrm{C}$. The heated serum was stored at $5^{\circ} \mathrm{C}$ and used on the following day. Sera from nine groups of mice were tested for their ability to induce degeneration of the acrosome. The groups involved the following animals: (1) mature males (control group); (2) oestrous females (confirmed by vaginal smears); (3) pregnant females (bled on the 11 th day of pregnancy); (4) females treated with progesterone $(1.0 \mu \mathrm{g} /$ day for 5 days $) ;(5)$ ovariectomized females (bled 10 days after ovariectomy); (6) ovariectomized females treated with $1.0 \mu \mathrm{g}$ oestrogen/day for 5 days; (7) intact females treated with $1.0 \mu \mathrm{g}$ oestrogen/day for 5 days; (8) intact females treated with $0.5 \mu$ g oestrogen/day for 5 days; (9) intact females treated with $0 \cdot 1 \mu \mathrm{g}$ oestrogen/day for 5 days.

Table 1. Induction of acrosome degeneration by serum collected from mature male mice and from female mice under various hormonal states

\begin{tabular}{|c|c|c|c|c|c|}
\hline \multirow{2}{*}{$\begin{array}{l}\text { Serum } \\
\text { from } \\
\text { mice in } \\
\text { Group } \dagger\end{array}$} & \multirow{2}{*}{$\begin{array}{c}\text { Total } \\
\text { no. of } \\
\text { animals }\end{array}$} & \multicolumn{4}{|c|}{$\begin{array}{c}\text { Spermatozoa }(\%) \text { without acrosomes at various times }(h r) \\
\text { after incubation with sera }\end{array}$} \\
\hline & & 0 & 2 & 4 & 6 \\
\hline $\begin{array}{l}1 \\
2 \\
3 \\
4 \\
5 \\
6 \\
7 \\
8 \\
9\end{array}$ & $\begin{array}{l}160^{*} \\
169 \\
119 \\
129 \\
129 \\
169 \\
149 \\
169 \\
129\end{array}$ & $\begin{array}{r}11 \cdot 5 \pm 2.5 \\
8 \cdot 2 \pm 3 \cdot 1 \\
9.5 \pm 3 \cdot 5 \\
11 \cdot 2 \pm 4.1 \\
13 \cdot 4 \pm 3 \cdot 2 \\
11 \cdot 3 \pm 2 \cdot 9 \\
12 \cdot 6 \pm 2 \cdot 8 \\
10.5 \pm 3 \cdot 1 \\
8.7 \pm 2 \cdot 8\end{array}$ & $\begin{array}{l}17 \cdot 2 \pm 3 \cdot 1 \\
16 \cdot 6 \pm 2 \cdot 6 \\
19 \cdot 5 \pm 4 \cdot 2 \\
17 \cdot 8 \pm 3 \cdot 8 \\
16 \cdot 3 \pm 4 \cdot 7 \\
19 \cdot 5 \pm 3 \cdot 5 \\
18 \cdot 3 \pm 3 \cdot 2 \\
17 \cdot 2 \pm 3 \cdot 2 \\
15 \cdot 9 \pm 4 \cdot 8\end{array}$ & $\begin{array}{l}27 \cdot 1 \pm 4 \cdot 4 \\
21 \cdot 3 \pm 3 \cdot 8 \\
22 \cdot 9 \pm 3 \cdot 4 \\
23 \cdot 4 \pm 4 \cdot 6 \\
24 \cdot 5 \pm 5 \cdot 8 \\
40 \cdot 3 \pm 5 \cdot 1 \\
35 \cdot 4 \pm 3 \cdot 6 \\
28 \cdot 4 \pm 2 \cdot 8 \\
26 \cdot 7 \pm 3 \cdot 3\end{array}$ & $\begin{array}{l}28 \cdot 5 \pm 3 \cdot 9 \\
23 \cdot 3 \pm 3 \cdot 2 \\
28 \cdot 9 \pm 4 \cdot 3 \\
28 \cdot 1 \pm 2 \cdot 1 \\
27 \cdot 2 \pm 5 \cdot 5 \\
56 \cdot 3 \pm 4 \cdot 8 * \\
51 \cdot 5 \pm 4 \cdot 3^{*} \\
30 \cdot 9 \pm 5 \cdot 2 \\
33.7 \pm 3 \cdot 8\end{array}$ \\
\hline
\end{tabular}

The results are expressed as means \pm S.E. Four experiments were carried out with the sera from the mice in each group.

* Significantly different from the controls by the $t$ test $(P<0.05)$.

$\dagger$ For a description of the mice in the control and experimental groups, see text.

For incubation, sperm suspension and serum were mixed together in the ratio of 3:I under mineral oil in tissue culture Petri dishes and incubated at $37^{\circ} \mathrm{C}$ for $6 \mathrm{hr}$ in an atmosphere of $5 \% \mathrm{CO}_{2}$ in air. At regular intervals, spermatozoa were removed from the culture droplets and analysed under a phase-contrast microscope. For the preparation of permanent slides, a drop of the sample was placed on a slide and spread by another slide as in the preparation of a blood film. The slides were then allowed to dry in air at room temperature and were stained by Bryan's triple stain (Bryan, 1970). For each experiment, 500 spermatozoa were counted at random from duplicate slides and the percentage of spermatozoa without an acrosome was calculated.

The results of the experiments are shown in Table 1. Of the serum samples assayed, only those from the mice in Groups 6 and 7 produced a significantly 
$(P<0.05)$ high percentage of acrosome degeneration after incubation for $6 \mathrm{hr}$. Both these groups involved females treated with $1.0 \mu \mathrm{g}$ oestrogen/day for 5 days. Lower doses of oestrogen did not produce any significantly different result, nor did the serum of oestrous females. The serum from pregnant females or from females treated with progesterone had no inhibitory effect on acrosome degeneration. The uterine horns of all the females treated with oestrogen and progesterone showed signs, such as an increase in weight, indicating that the treatment was effective.

The results of our experiments did not show any relationship between the hormonal state of the female and the ability of the blood serum to induce acrosome degeneration. (The expression 'acrosome reaction' has been avoided because it is not known whether the effect observed here is a 'true' acrosome reaction, a 'false' acrosome reaction, or only a post-mortem change.) There was no substantial difference between the effect of serum from male and female animals. In hamsters, Barros et al. (1972) found cyclic changes throughout the oestrous cycle in the ability of blood serum to induce the acrosome reaction. Though we have not studied the complete cycle, the fact that there was no significant difference between the effect of the serum from oestrous females and that from males shows that there cannot be any such cyclic change in the mouse. Yanagimachi (1970) also could not find any difference between the ability of serum from male and female hamsters to capacitate hamster spermatozoa.

The acrosomes of mouse spermatozoa seem to be more stable than the acrosomes of hamster spermatozoa. When incubated in the presence of serum prepared from oestrous females, $65 \%$ of hamster spermatozoa lost their acrosomes in $5 \mathrm{hr}$ (Barros et al., 1972). Under similar conditions, only $28 \%$ of mouse spermatozoa lost their acrosomes in $6 \mathrm{hr}$. Oestrogen in very high doses did produce more than $50 \%$ of spermatozoa with acrosome degeneration, but the difference became significant only after incubation for $6 \mathrm{hr}$. According to Iwamatsu \& Chang (1970) and Oliphant \& Brackett (1973), the time required for the capacitation of mouse spermatozoa is 1 to $2 \mathrm{hr}$. In our experiments, only 15 to $20 \%$ of spermatozoa had lost their acrosomes after incubation for $2 \mathrm{hr}$. After subtracting the number of spermatozoa which had already lost their acrosomes at the start of the experiment, not more than 5 to $10 \%$ of spermatozoa were capacitated in $2 \mathrm{hr}$, if acrosome degeneration is regarded as a necessary concomitant of capacitation. It is possible, however, that mouse spermatozoa may resemble rabbit spermatozoa in which an acrosome reaction is not a morphological concomitant of capacitation (Bedford, 1969). Oliphant \& Brackett (1973) have reported the successful capacitation, decapacitation and recapacitation of mouse spermatozoa. If capacitation of mouse spermatozoa involves the removal of the acrosome (and not merely a surface coat), it is highly improbable that decapacitation is ever possible. Furthermore, even after repeated trials, the present authors could not find a single mouse spermatozoon which remained motile after removal of the acrosome and this again indicates a fundamental difference from hamster spermatozoa. It appears, therefore, that mouse spermatozoa differ from hamster spermatozoa in regard to capacitation and the acrosome reaction. 
We are grateful to Professor P. N. Srivastava and Professor A. S. Kapoor for their valuable suggestions.

\section{REFERENCES}

Barros, G., Arrau, J. \& Herrera, E. (1972) Induction of the acrosome reaction of golden hamster spermatozoa with blood serum collected at different stages of the oestrous cycle. 7 . Reprod. Fert. 28, 67-76.

Barros, C. \& Garavagno, A. (1970) Gapacitation of hamster spermatozoa with blood sera. F. Reprod. Fert. 22, 381-384.

Bedrord, J. M. (1969) Morphological aspects of capacitation. Adv. Biosci. 4, 35-50.

BracketT, B. G. (1969) In vitro fertilization of mammalian ova. Adv. Biosci. 4, 73-94.

BRYAN, J. H. D. (1970) An eosin-fast green-naphthol yellow mixture for differential staining of cytologic components in mammalian spermatozoa. Stain Technol. 45, 231-236.

Iwamatsu, T. \& Chang, M. G. (1970) Further investigation of capacitation of sperm and fertilization of mouse eggs in vitro. 7. exp. Zool. 175, 271-282.

OliphaNt, G. \& BRACKETT, B. (1973) Gapacitation of mouse spermatozoa in media with elevated ionic strength and reversible decapacitation with epididymal extracts. Fert. Steril. 24, 948-955.

YANAGIMACHI, R. (1970) In vitro capacitation of golden hamster spermatozoa by homologous and heterologous blood sera. Biol. Reprod. 3, 147-153. 